\title{
AKSELERASI:
}

JURNAL PENDIDIKAN GURU MI

Volume 2, Nomor 2, Desember 2021, Hal. 103-122

\section{IMPLEMENTASI PEMBELAJARAN BERBASIS MULTIPLE INTELLIGENCES DI SD HIDAYATUL MURID FULL DAY AMPEL WULUHAN JEMBER}

\author{
Nilta Nur Af'idah', Mohammad Kholil ${ }^{2}$ \\ ${ }^{1}$ UIN Kiai Haji Achmad SiddiqJember, Jl. Mataram No.1 Mangli Jember, Jawa Timur Indonesia \\ e-mail: niltanurafidah@gmail.com \\ ${ }^{2}$ UIN Kiai Haji Achmad Siddiq Jember, Jl. Mataram No.1 Mangli Jember, Jawa Timur Indonesia \\ e-mail: mkholi10686@gmail.com
}

\begin{abstract}
The low index of human development in Indonesia and the low ranking of Indonesia in ranking a country's competitiviness based on the ability or talents of human resources by Global Talent Competitiviness Index in 2019 indicate the low ability to develop every intelligence or talent of students. Then, multiple intelligences based learning needs to be applied to develop every intelligence or talent of students. The focus of this research is how is the planning, implementation, and evaluation of multiple intelligences based learning in SD Hidayatul Murid Full Day Ampel Wuluhan Jember. The purpose of this research is to describe the planning, implementation, and evaluation of multiple intelligences based learning in SD Hidayatul Murid Full Day Ampel Wuluhan Jember. This research uses a qualitative approach to the type of case studies. Research subjects were determined using purposive sumpling techniques and data in this research were collected through observation, interviews, an documentation.
\end{abstract}

Keywords: Learning, Multiple Intelligences

\begin{abstract}
ABSTRAK
Rendahnya Indeks Pembangunan Manusia negara Indonesia dan rendahnya peringkat negara Indonesia dalam pemeringkatan daya saing suatu negara berdasarkan kemampuan atau talenta sumber daya manusia oleh Global Talent Competitiviness Index pada tahun 2019 menunjukkan rendahnya kemampuan untuk mengembangkan setiap kecerdasan atau bakat di negara Indonesia. Maka, pembelajaran berbasis multiple intelligences perlu diterapkan untuk mengembangkan setiap kecerdasan atau bakat peserta didik. Fokus penelitian ini adalah bagaimana perencanaan, pelaksanaan, dan evaluasi pembelajaran berbasis multiple intelligences di SD Hidayatul Murid Full Day Ampel Wuluhan Jember?. Tujuan penelitian ini adalah untuk mendeskripsikan perencanaan, pelaksanaan, dan evaluasi pembelajaran berbasis multiple intelligences di SD Hidayatul Murid Full Day Ampel Wuluhan Jember. Penelitian ini menggunakan pendekatan kualitatif, dengan jenis penelitian studi kasus. Subjek penelitian ditentukan menggunakan teknik purposive
\end{abstract}


sumpling dan data pada penelitian ini dikumpulkan melalui observasi, wawancara, dan dokumentasi.

Kata Kunci: Pembelajaran, Kecerdasan Majemuk

\section{PENDAHULUAN}

Pencapaian pembangunan Indonesia dalam bidang pendidikan masih menunjukkan ketertinggalan. Meskipun ada peningkatan Indeks Pembangunan Manusia (IPM) yaitu ukuran bagaimana penduduk dapat mengakses hasil pembangunan dalam memperoleh pendapatan, kesehatan, dan pendidikan. IPM Indonesia adalah 68,9 pada tahun 2014 meningkat menjadi 70,81 pada tahun 2017. Angka tersebut tergolong tinggi namun angka tersebut masih menempatkan Indonesia pada urutan 116 dari 189 negara (Tim Penyusun, 2018: 4).

Sementara itu, berdasarkan Global Talent Competitiviness Index (GTCI) yaitu pemeringkatan daya saing negara berdasarkan kemampuan atau talenta sumber daya manusia yang dimiliki suatu negara, pada tahun 2019 Indonesia berada di peringkat 67 dari 125 negara dengan skor 38,61 dan berada di peringkat 6 dalam urutan negara ASEAN. Beberapa indikator penilaian indeks ini adalah pendapatan per kapita, pendidikan, infrastruktur teknologi komputer dan informasi, gender, lingkungan, tingkat toleransi, hingga stabilitas politik (Lanvin \& Felipe Monteiro, 2019: 11-13).

Keadaan tersebut menunjukkan rendahnya kemampuan atau talenta sumber daya manusia Indonesia. Padahal menurut Howard Gardner (1983: xxviii) setiap manusia memiliki kecerdasan. Kecerdasan yang dimaksud oleh Gardner bukan hanya sekedar kecerdasan dalam menyelesaikan soal-soal ujian yang cenderung pada nilai kognitif saja. Gardner berpendapat bahwa "An intelligence is the ability to solve problems, or to create products, that are valued within one or more cultura Settings". Pernyataannya tersebut menjelaskan bahwa kecerdasan adalah kemampuan memecahkan masalah, membuat karya atau produk, yang merupakan konsekuensi dalam satu keadaan budaya atau masyarakat tertentu. Kecerdasan yang dimiliki manusia dapat dikembangkan terus menerus hingga dapat menjadikan manusia-manusia yang unggul.

Multiple intelligences dikemukakan oleh Gardner pada tahun 1983. Ketika dipublikasikan pertama kali, hanya disampaikan ada 7 macam kecerdasan. Namun setelah diadakan penelitian lebih lanjut ada 9 macam kecerdasan yaitu, kecerdasan linguistik (bahasa), kecerdasan logika dan matematika (matematis-logis), kecerdasan visual-spasial, kecerdasan kinestetika (raga), kecerdasan interpersonal, kecerdasan intrapersonal, kecerdasan musik, kecerdasan naturalis, dan kecerdasan eksistensial (Helmawati, 2018: 54).

Karunia yang dimiliki manusia dengan 9 macam kecerdasan menunjukkan bahwa manusia adalah sebaik-baiknya makhluk. Hal tersebut telah dijelaskan dalam Q.S At-Tiin ayat 4 bahwa manusia diciptakan Allah SWT dalam bentuk yang sebaik-baiknya: 


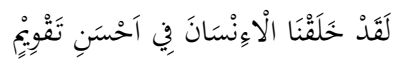

Artinya : "Sesungguhnya Kami telah menciptakan manusia dalam bentuk yang sebaikbaiknya".

Para mufassir menjelaskan bahwa kata-kata "dalam bentuk yang sebaik-baiknya" bukan hanya dari sisi fisik atau kondisi kesempurnaan tubuh manusia saja. Kondisi tersebut hanya salahsatu keistimewaan yang diberikan oleh Allah SWT. Allah memberikan keistimewaan yang lebih berupa potensi mental dan spiritual hingga dapat mendayagunakan akal. Potensi manusia tersebut dapat dilihat dari temuan di bidang ilmu pengetahuan seperti kedokteran, neurologi, dan fisiologi (Baiquni, 2014: 363).

Multiple intelligences jika dioptimalkan dengan baik akan meningkatkan sumber daya manusia. Karena setiap kecerdasan manusia tersebut sangat dibutuhkan dalam setiap sisi kehidupan dan saling memberikan manfaat satu sama lain. Meskipun begitu, setiap manusia tidak bisa menguasai semua kecerdasan tersebut, ada kecenderungan kecerdasan yang dimiliki. Setiap manusia akan berprestasi sesuai dengan kecenderungan yang dimiliki. Misalnya, ilmuwan yang bernama Al-Kindi, yang mengembangkan kecerdasan matematis-logis sehingga menjadi ahli matematika yang memiliki teori serta konsep keilmuwaan yang kemudian dikembangkan oleh orang-orang barat. Thomas Alva Edison mampu mengembangkan kecerdasan naturalis dalam menemukan lampu (listrik). JK Rowling mampu mengembangkan kecerdasan linguistik sehingga bisa menulis novel terkenal Harry Potter (Helmawati, 2018: 7).

Salah satu cara untuk mengoptimalkan potensi multiple intelligences adalah melalui pendidikan. Karena fungsi dan tujuan diselenggarakannya pendidikan nasional adalah mengembangkan kecerdasan dan potensi seperti yang terdapat dalam UU No. 20 Tahun 2003 tentang Sistem Pendidikan Nasional bab 2 pasal 3 berikut:

Pendidikan nasional berfungsi mengembangkan kemampuan dan membentuk watak serta peradaban bangsa yang bermartabat dalam rangka mencerdaskan kehidupan bangsa, bertujuan untuk berkembangnya potensi peserta didik agar menjadi manusia yang beriman dan bertakwa kepada Tuhan Yang Maha Esa, berakhlak mulia, sehat, berilmu, cakap, kreatif, mandiri, dan menjadi warga negara yang demokratis serta bertanggung jawab.

Dalam proses pendidikan, manusia (selanjutnya disebut dengan peserta didik) bisa mengembangkan kecerdasannya dengan belajar. Karena belajar adalah inti dari pendidikan. Belajar adalah proses perubahan tingkah laku peserta didik. Proses peserta didik belajar di Sekolah berarti melibatkan interaksi dengan guru dan sumber belajar. Oleh karena itu, proses tersebut dinamakan dengan pembelajaran.

Pembelajaran yang berbasis multiple intellegences adalah pembelajaran yang memperhatikan 9 macam kecerdasan yang dimiliki peserta didik. Pembelajaran berbasis multiple intelligences telah diterapkan di beberapa Sekolah di Indonesia seperti SD Yayasan Islam Malik 
Ibrahim Fullday School yang didirikan oleh Munif Chatib di Gresik, Sekolah Dasar YIMA Bondowoso, (Chatib, 2018: 52, 54) dan SD Jogja Green School (Dzilhijjah, 2016: 1968).

Sementara itu, di kabupaten Jember pembelajaran berbasis multiple intellegences diterapkan oleh salah satu pendidikan dasar yaitu SD Hidayatul Murid Full Day. Berdasarkan penuturan Kepala Sekolah yaitu Bapak Muhammad Syafi'ul Fuadi (Wawancara, 15/11/2019), Sekolah ini menerapkan multiple intelligences karena ingin menghargai setiap bakat atau kecerdasan peserta didik, mengajar dan membimbing mereka dengan kasih sayang karena mereka telah dipercayakan oleh orang tuanya kepada Sekolah. Guru juga tidak menuntut nilai kepada peserta didk, karena mempercayai bakat atau kecerdasan selain dari sisi akademik.

Pembelajaran berbasis multiple intelligences di SD Hidayatul Full Day mempunyai keunikan tersendiri yaitu menjadikan pembelajaran berbasis multiple intelligences sebagai cara untuk mewujudkan Sekolah ramah anak dengan pendekatan kasih sayang, membentuk karakter disiplin peserta didik dengan kecerdasan atau bakat yang mereka punya, tanpa perlu ada teriakan atau hukuman fisik dan berprestasi sesuai keunggulan masing-masing. Misalnya, disini ada peserta didik yang tidak bisa diam saat di kelas, kecerdasan kinestetiknya sangat menonjol, dia tidak pernah bisa diam duduk. Oleh karena itu, guru tidak menuntutnya untuk diam, akan tetapi disalurkan kepada kegiatan positif seperti saat kelas kotor, dia menjadi anak yang paling semangat untuk bergerak membersihkan tanpa disuruh. Jadi dia tetap bisa disiplin dengan kecerdasan kinestetiknya, tanpa menuntutnya untuk diam (Tohari, Wawancara 01/02/2020).

Berdasarkan keunikan penerapan pembelajaran berbasis multiple intelligences yang diterapkan oleh SD Hidayatul Murid Full Day peneliti tertarik untuk melakukan penelitian mengenai implementasi pembelajaran berbasis multiple intelligences di Sekolah tersebut. adapun tujuan dari penelitian ini adalah mendeskripsikan mengenai perencanaan, pelaksanaan, serta evaluasi pembelajaran berbasis multiple intelligences di SD Hidayatul Murid Full Day Ampel Wuluhan.

\section{METODE}

Penelitian ini menggunakan pendekatan kualitatif dengan jenis penelitian studi kasus. Penelitian dilaksanakan pada bulan januari- februari 2020 di SD Hidayatul Murid Full Day yang berlokasi di desa Ampel, Wuluhan, Jember. Subjek penelitian ditentukan menggunakan teknik purposive sumpling dengan memperhatikan beberapa hal. Subjek penelitian yang dipilih adalah Guru Kelas IV, peserta didik kelas IV, pendiri yayasan, dan Kepala Sekolah.

Data pada penelitian ini adalah data kualitatif berupa kata-kata atau teks naratif. Oleh karena itu teknik pengumpulan data menggunakan observasi, wawancara, dan dokumentasi. Data yang didapatkan kemudian dianalisis menggunakan model Miles, Huberlman, dan Saldana. Pada saat proses analisis data, peneliti melakukan 3 hal setelah mengumpulkan data (data collection) 
yaitu kondensasi data (data condensation), penyajian data (data display), dan kesimpulan/verifikasi (conclusion drawing/verification). Untuk mengetahui keabsahan data, peneliti melakukan triangulasi sumber dan teknik.

\section{HASIL DAN PEMBAHASAN}

\section{Perencanaan Pembelajaran Berbasis Multiple Intelligences}

Pada tahap perencanaan pembelajaran berbasis multiple intelligences ada dua hal yang dilakukan oleh pihak SD Hidayatul Murid Full Day. Pertama, mengetahui kecerdasan atau bakat peserta didik. Kedua, menyusun Rencana Pelaksanaan Pembelajaran (RPP).

Mengetahui kecerdasan atau bakat peserta didik dilaksanakan pada saat peserta didik akan masuk di kelas 1 dengan melakukan wawancara kepada orang tua peserta didik dan tes kemampuan peserta didik. Kemudian, orang tua peserta didik juga diharuskan bertemu pendiri yayasan untuk menyamakan visi misi Sekolah dan orang tua. Dalam hal ini, guru kelas IV, Ibu Khusnul Fitriani (Wawancara, 28.01/2020), menyampaikan bagaimana cara guru dapat mengetahui kecenderungan kecerdasan yang dimiliki peserta didik.

"Iya memang ada wawancara dan tes di awal, tapi kita juga amati dari keseharian mereka bisa diketahui misal ketika selalu dikasih pertanyaan dia tidak pernah nyambung, ternyata dia di bidang olah raga yang lebih menonjol, ada juga di pelajaran juga tidak begitu menerima, namun ketika di paduan suara dia punya kemampuan yang baik."

Kepala Sekolah, yaitu Bapak Muhammad Syafi'ul Fuadi, juga menyampaikan bahwa guru kelas harus dekat dengan peserta didik sehingga mengetahui masing-masing karakter dan bakat mereka (Wawancara, 03/02/2020). Selain itu, pendiri yayasan yaitu Bapak Tohari, juga menambahkan bahwa wawancara dilakukan untuk mengetahui kemampuan dan kesukaan peserta didik. Wawancara ini sebagai ganti dari tes Multiple Intelligences Reseacrh (MIR) karena terkendala biaya. Pendiri yayasan juga berpendapat bahwa wawancara dirasa lebih valid karena disampaikan langsung oleh orang tua yang mengetahui keseharian peserta didik (Wawancara, 01/02/2020).

Pelaksanaan wawancara sebagai pengganti tes multiple intelligences mempunyai kelebihan tersendiri karena datanya didapatkan dari orang tua yang mana menurut Munif Chatib (2018: 94), orang tua adalah faktor eksternal yang dapat menjadi pemicu untuk memunculkan kecerdasan atau potensi yang dimiliki peserta didik dan orang tua yang setiap hari bersama peserta didik. Selain itu, waku pelaksanaannya juga sudah tepat, karena waktu yang tepat untuk menemukan kecerdasan peserta didik adalah saat peserta didik masih dalam golden age, yaitu ketika sejak baru lahir sampai peserta didik berusia 8 tahun (Chatib, 2018: 94).

Meskipun begitu, masih belum diketahui tingkat efektivitas wawancara tersebut untuk mengetahui kecerdasan atau bakat anak dan hanya dilakukan pada saat akan masuk kelas 1 . Hal 
tersebut dikarenakan menurut Howard Gardner kecerdasan atau bakat peserta didik itu bisa berkembang dan tidak statis. Maka, kecerdasan atau bakat peserta didik itu harus diketahui secara berkala, misalnya setiap kenaikan kelas (Chatib, 2018: 94).

Hal lain yang dilaksanakan pada tahap perencanaan pembelajaran berbasis multiple intelligences adalah menyusun Rencana Pelaksanaan Pembelajaran (RPP). RPP yang digunakan adalah RPP kurikulum 2013. Guru kelas IV menyampaikan bahwa RPP yang digunakan tetap menggunakan RPP kurikulum 2013 karena mengikuti aturan dari pemerintah, dan dikembangkan pada bagian kegiatan pembelajarannya (Fitriani, Wawancara, 28/01/2020).

Sedangkan menurut pendiri yayasan, langkah-langkah pembelajaran berbasis multiple intelligences yang ada tiga yaitu alpha zone, scene setting/warmer, dan aktivitas memang tidak disebutkan secara rinci di RPP. Namun, konteks dari langkah-langkah pembelajaran tersebut sudah termuat di dalam RPP kurikulum 2013 (Tohari, Wawancara, 01/02/2020).

Peneliti juga menganalisis dokumen Rencana Pelaksanaan Pembelajaran (RPP) yang pernah dibuat dan diterapkan oleh Guru kelas IV pada semester sebelumnya. Dari data tersebut, Rencana Pelaksanaan Pembelajaran (RPP) berisi idenditas Sekolah, tema, sub-tema, pembelajaran ke berapa, fokus pembelajaran, alokasi waktu, kompetensi inti, kompetensi dasar, indikator, tujuan pembelajaran, materi pembelajaran, metode pembelajaran, media/alat, bahan serta sumber belajar, langkah-langkah kegiatan pembelajaran, dan penilaian.

Berdasarkan data tersebut, dapat disimpulkan bahwa RPP yang digunakan dalam pembelajaran berbasis multiple intelligences di SD Hidayatul Murid Full Day menggunakan RPP kurikulum 2013, namun masih belum revisi.

\section{Pelaksanaan Pembelajaran Berbasis Multiple Intelligences}

Pembelajaran berbasis multiple intelligences mempunyai tiga langkah pembelajaran. Pertama, diawali dengan kegiatan alpha zone. Kedua, scene setting/warmer. Ketiga, aktivitas yang didalamnya memuat strategi pembelajaran dan penggunaan media atau teaching aids.

Pembelajaran diawali dengan kegiatan alpha zone. Alpha zone adalah kegiatan menyenangkan untuk membuka pembelajaran, bisa dengan menyanyi, ice breaking, dan senam otak (Chatib, 2018: 52-56). Adapun kegiatan alpha zone yang ditemukan pada saat observasi sangat beragam yaitu, guru mengajak peserta didik melakukan snam otak dengan gerakan tertentu sambil menyanyikan lagu anak-anak "naik-naik ke puncak gunung", menyanyikan lagu daerah berbahasa jawa yang berjudul "kidang talun" dan "gajah belang", beberapa kreasi tepuk, menyerukan yel-yel kelas, menyanyikan lagu yang berisi menanyakan kabar peserta didik, dan menyanyikan lagu anjuran membaca basmalah sebelum melakukan sesuatu.

Guru kelas IV menuturkan bahwa kegiatan alpha zone dilakukan agar peserta didik semangat dengan mengajak mereka tepuk-tepuk, bernyanyi. Dengan begitu perhatian mereka akan terpusat pada guru. Sedangkan senam otak yang dilakukan berguna untuk mengajarkan 
konsentrasi (Fitriani, Wawancara 28/01/2020). Pernyataan tersebut sesuai dengan apa yang disampaikan salah satu peserta didik kelas IV bahwa untuk memulai belajar, biasanya diajak untuk menyanyi, yel-yel, senam otak, yang berganti-ganti setiap hari (Kafabi, Wawancara 17/01/2020).

Dari hasil temuan tersbut, dapat disimpulkan bahwa kegiatan yang dilakukan saat alpha zone sudah tepat karena sesuai dengan pendapat Chatib (2018: 52-56) bahwa kegiatan alpha zone adalah kegiatan yang menyenangkan untuk membuka pembelajaran. Berikut ini adalah salahsatu dokumentasi saat kegiatan alpha zone melakukan senam otak.

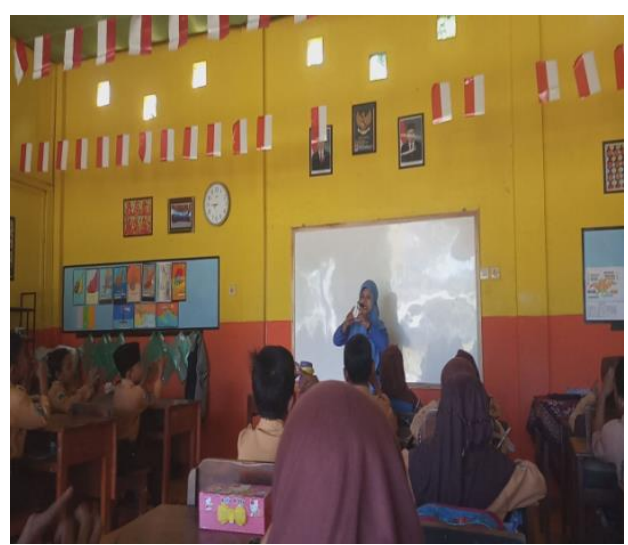

Gambar 1. Kegiatan alpha zone

Langkah pembelajaran yang kedua adalah scene setting, yaitu membangun konsep pembelajaran seperti dengan cerita, lalu guru menanyakan isi cerita untuk mengajak peserta didik masuk pada materi. Apabila pembelajaran melanjutkan materi sebelumnya kegiatan scene setting bisa digantikan dengan kegiatan warmer yaitu mengingat kembali materi sebelumnya (Chatib, 2018: 52-56).

Kegiatan scene setting yang ditemukan pada saat observasi adalah guru menunjukkan sebuah media pembelajaran berupa kertas untuk membawa peserta didik memasuki materi mengenai bangun datar persegi. Sedangkan kegiatan warmer yang dilakukan adalah menanyakan kepada peserta didik tentang materi sebelumnya seperti, "apa yang dinamakan rima?", “apa contoh Sumber Daya Alam yang dapat diperbarui?”, dan “apa Sumber Daya Alam yang tidak dapat diperbarui?".

Guru kelas IV menuturkan bahwa pertanyaan-pertanyaan itu berguna untuk review materi sebelumnya, karena tidak semua peserta didik mengingat materi sebelumnya, maka dengan mendengarkan peserta didik lainnya yang menjawab bisa mengingatkan peserta didik dengan materi sebelumnya (Fitriani, Wawancara 28/01/2020). Salah satu peserta didik juga menyampaikan bahwa guru mengulang materi sebelumnya dengan menunjuk peserta didik secara acak untuk menjawab pertanyaan yang berkaitan dengan materi sebelumnya (Kafabi, Wawancara 17/01/2020). Hasil temuan mengenai kegiatan scene setting/warmer tersebut 
sesuai dengan pendapat Chatib (2018: 52-56) bahwa scene setting adalah membangun konsep pembelajaran, dan warmer adalah mengingat kembali materi sebelumnya. Berikut ini adalah salahsatu dokumentasi kegiatan scene setting saat guru menggunakan media berupa kertas yang berbentuk persegi.

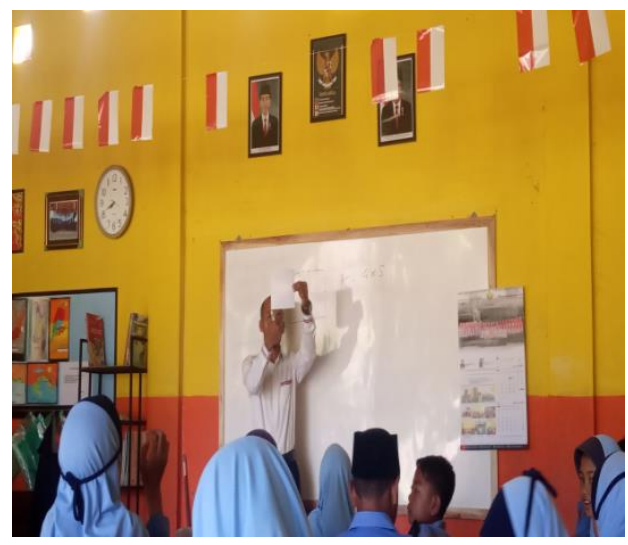

Gambar 2. Kegiatan scene setting

Langkah pembelajaran berikutnya adalah aktivitas yaitu rangkaian kegiatan yang dilakukan beserta strategi pembelajarannya, dan teaching aids atau penggunaan media. Guru menerapkan beberapa aktivitas untuk mengembangkan sembilan macam kecerdasan yang dimiliki peserta didik seperti berikut.

a. Kecerdasan verbal/bahasa (verbal/linguistic intelligence)

Kecerdasan verbal/bahasa adalah kecerdasan tentang semua hal yang berkaitan dengan kata-kata dan bahasa, diekspresikan dengan kegiatan seperti membaca dan menulis puisi, bercerita, dan berpikir simbolik (Budiningsih, 2015: 114). Aktivitas kecerdasan bahasa yang ditemukan pada saat penelitian adalah menulis puisi dengan tema tertentu yang sebelumnya guru juga sudah membacakan salahsatu contoh puisi, tanya jawab saat peserta didik mengerjakan soal matematika serta menjelaskan bagaimana cara pengerjaannya dan cara menemukan jawabannya, praktek mendeklamasikan salahsatu puisi yang ada di buku, diskusi dengan teman sekelompok untuk mengerjakan soal, dan membaca nyaring saat membahas soal-soal yang sudah dikerjakan. Dari aktivitas tersebut juga dapat diketahui bahwa teaching aids atau media yang digunakan berupa teks puisi.

Guru kelas juga menambahkan aktivitas kecerdasan verbal/bahasa yang pernah dilakukan adalah menulis cerita pengalaman saat mereka libur semester, serta pelafalan yang benar saat membaca (Fitriani, Wawancara 28/01/2020). Salahsatu peserta didik juga menyampaikan bahwa guru pernah meminta untuk maju ke depan menceritakan pengalaman selama libur panjang, dan juga membaca puisi. Selain itu juga diingatkan untuk membaca buku pelajaran saat akan diadakan ulangan (Muribbiyatuz Z, Wawancara 
17/01/2020). Berikut ini adalah salahsatu dokumentasi aktivitas kecerdasan verbal/bahasa saat mendeklamasikan puisi.

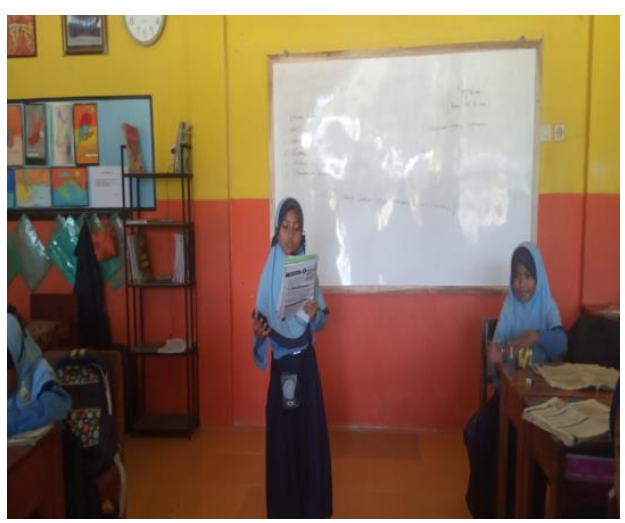

Gambar 3. Aktivitas kecerdasan verbal/bahasa

Aktivitas kecerdasan verbal/bahasa yang sudah dilakukan sesuai dengan pendapat Helmawati (2018: 65-72) bahwa kecerdasan verbal linguistik diajarkan melalui berbicara, menulis, bercerita, dan permainan kata. Sedangkan menurut Armstrong (2009: 74-76) strategi yang dapat dilakukan untuk kecerdasan verbal linguistik adalah bercerita, brainstorming, menyediakan media pembelajaran berupa rekaman, dan menulis jurnal.

Dari pemaparan di atas, dapat diketahui bahwa aktivitas kecerdasan verbal/bahasa banyak dilakukan pada muatan bahasa Indonesia, padahal menurut Chatib (2018: 97-98) kecerdasan verbal/bahasa bukan merupakan pelajaran Bahasa Indonesia, tapi sebuah penamaan kecerdasan dan ketika masuk pada pembelajaran menjadi strategi pembelajaran agar peserta didik yang memiliki kecenderungan verbal/bahasa dapat memahami materi pembelajaran. Jadi, aktivitas kecerdasan verbal/bahasa juga perlu dilakukan pada saat muatan pelajaran lain untuk memudahkan peserta didik memahami materi lain.

b. Kecerdasan logika-matematika (logical/matematical intelligence)

Kecerdasan logika-matematika adalah kecerdasan menggunakan angka-angka secara efektif seperti ahli matematika, akuntan pajak, atau ahli statistik. Dapat bernalar dengan baik dan peka terhadap pola dan hubungan yang logis, proposisi (hubungan sebab dan akibat) (Armstrong, 2009: 6). Pendapat lain menambahkan bahwa berpikir ilmiah, berpikir deduktif dan induktif serta dapat menghadapi masalah atau tantangan baru dan berusaha menghadapinya juga termasuk kecerdasan ini (Budiningsih, 2015: 114).

Aktivitas kecerdasan logika-matematika yang ditemukan saat observasi adalah menghitung bait dan baris puisi, mengidentifikasi unsur intrinsik puisi, membadakan bentuk suatu benda yang berbetuk persegi dan bukan persegi, guru menjelaskan cara menghitung luas bangun datar yaitu persegi dan segitiga, peserta didik menyelesaikan soal cerita yang berkaitan dengan persegi dan segitiga, serta menyelesaikan soal-soal dan guru 
memberikan tanggapan dengan menanyakan alasan jawaban-jawaban mereka. Dari aktivitas tersebut dapat diketahui bahwa teaching aids atau media yang digunakan berupa benda-benda yang berbentuk bangun datar.

Guru kelas IV menyampaikan bahwa untuk aktivitas logika-matematika yang dilakukan adalah mengenal bentuk-bentuk bangun, juga mengajarkan peserta didik untuk berfikir logis dengan meminta mereka melakukan analisis yang sederhana seperti saat selesai mengerjakan soal-soal dan pendapat mereka tentang penyebab suatu kejadian bencana alam (Fitriani, Wawancara 28/01/2020). Salahsatu peserta didik juga menyampaikan bahwa guru pernah mengajak untuk mengukur benda di sekitar yaitu meja dan kursi, serta menghitung saat pelajaran matematika (Adabie, Wawancara, 22/01/2020). Berikut ini adalah salahsatu aktivitas kecerdasan logika-matematika saat peserta didik menyelesaikan soal mencari luas persegi.

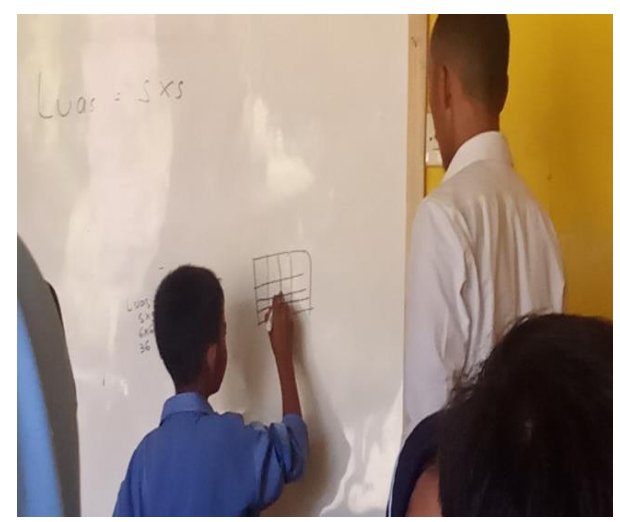

Gambar 4. Aktivitas kecerdasan logika-matematika

Berdasarkan data tersebut, aktivitas kecerdasan logika-matematia yang dilakukan sesuai dengan pendapat Helmawati (2018: 118-132) bahwa strategi yang dapat digunakan untuk mengembangkan kecerdasan logika-matematika adalah mengenal, mengurutkan dan menunjukkan angka, menghitung, membedakan bentuk, menganalisis, dan mengemukakan alasan dan argumen masing-masing. Begitu juga dengan pendapat Armstrong (2009: 7679) yang berpendapat bahwa strategi pembelajaran untuk kecerdasan logika-matematika adalah menghitung, mengelompokkan atau mengkategorikan sesuatu, socrates questioning (tanya jawab), pemecahan masalah, dan berpikir ilmiah.

c. Kecerdasan visual-spasial (visual/spatial intelligence)

Kecerdasan visual-spasial adalah Kecerdasan melihat suatu objek dengan detail dan akurat dan mampu membuat transformasi dari objek yang dilihat. Kecerdasan ini melibatkan kepekaan terhadap warna, garis, bayangan, bentuk, ruang, serta hubungan dari elemen-elemen tersebut atau senirupa. Termasuk kecerdasan memvisulisasikan dan 
menuangkan ide-idenya dalam bentuk visual-spasial, permainan catur, navigasi, dan arsitektur (Armstrong, 2009: 6).

Aktivitas kecerdasan visual-spasial yang dilakukan adalah mengamati gambar mengenai Sumber Daya Alam, menggambar bangun datar persegi dan segitiga, dan mengamati lingkungan sekitar sekolah saat belajar di sekitar sekolah. Aktivitas kecerdasan visual-spasial juga dikembangkan pada kegiatan bakat minat yang diadakan setiap hari Sabtu berupa kegiatan melukis dan kaligrafi. Untuk aktivitas kecerdasan visual-spasial pada kegiatan bakat minat hanya diikuti peserta didik yang memiliki kecenderungan kecerdasan atau bakat kecerdasan visual-spasial. Dari aktivitas-aktivitas tersebut dapat diketahui bahwa teaching aids atau penggunaan media pada kecerdasan ini berupa gambar dan juga alat-alat untuk melukis.

Guru kelas IV menyampaikan bahwa kecerdasan ini berkaitan dengan aktivitas menggambar, mewarnai, membuat origami yang diberi foto peserta didik, membuat kolase dan batik. Hasil dari aktivitas tersebut dipajang di Kelas untuk mengapresiasi hasil karya peserta didik. Guru juga mengirim gambar-gambar materi melalui grup whatsapp ketika tidak bisa memfasilitasi saat pembelajaran di Kelas (Fitriani, Wawancara 28/01/2020). Salahsatu peserta didik juga menyampaikan bahwa mereka sering diajak untuk menggambar baik pada saat pembelajaran tematik, mengisi jam kosong, dan saat bakat minat (Rahma, Wawancara, 22/01/2020). Berikut ini adalah salahsatu dokumentasi aktivitas kecerdasan visual-spasial saat praktek membuat batik.

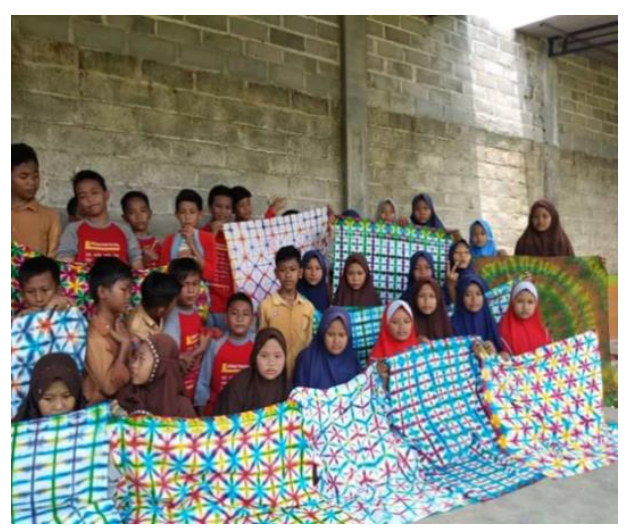

Gambar 5. Aktivitas kecerdasan visual-spasial

Aktivitas kecerdasan visual-spasial yang sudah dilakukan sudah sesuai karena kecerdasan visual-spasial adalah kecerdasan yang melibatkan indra penglihatan untuk melihat suatu objek dengan detail kemudian merekam dan menuangkannya dalam selembar kertas. Namun, ada banyak aktivitas yang belum dilakukan seperti bermain balok, bentuk geometri melalui puzzle, menonton film, cerita khayal ataupun dengan berimajinasi (Helmawati, 2018: 133-134). 
d. Kecerdasan kinestetik/tubuh (body/kinesthetic intelligence)

Kecerdasan kinestetik/tubuh adalah kecerdasan mengekspresikan ide dan perasaan melalui tubuhnya dan keterampilan fisik tertentu seperti keseimbangan, fleksibelitas, dan kekuatan (Armstrong, 2009: 7). Termasuk memadukan antara pikiran dan gerakan tubuh atau fisik sehingga menghasilkan gerakan dengan sempurna (Helmawati, 2018: 139-140).

Aktivitas kecerdasan ini dilakukan saat alpha zone melakukan senam otak, ice breaking, dan saat kegiatan olahraga. Aktivitas kecerdasan ini juga ditemukan pada kegiatan bakat minat futsal, catur, dan bola voly untuk peserta didik tertentu yang memiliki kecenderungan atau bakat kecerdasan kinestetik/tubuh. Bela diri menjadi bakat minat yang wajib diikuti untuk mengembangkan kecerdasan ini. Dari aktivitas-aktivitas tersebut dapat diketahui bahwa teaching aids atau media yang digunakan adalah alat-alat olahraga.

Guru kelas IV menyampaikan bahwa aktivitas kecerdasan ini dilakukan dengan kegiatan yang mengaktifkan gerak peserta didik, seperti menggunting, membuat kerajinan, tapi paling sering dilibatkan ketika olah raga, ice breaking, dan juga permainan (Fitriani, Wawancara 28/01/2020). Salahsatu peserta didik juga menyampaikan bahwa aktivitas yang mengajak mereka bergerak adalah senam otak, praktek olahraga.” (Kafabi, Wawancara 17/01/2020). Berikut ini salahsatu dokumentasi kecerdasan kinestetik/tubuh saat melakukan latihan bela diri.

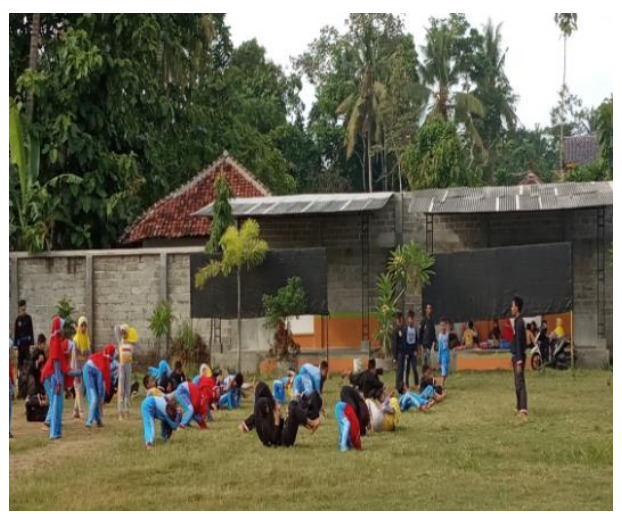

Gambar 6. Aktivitas kecerdasan kinestetik/tubuh

Berdasarkan hasil temuan tersebut aktivitas kecerdasan kinestetik/tubuh yang dilakukan karena menurut Helmawati (2018: 140) kecerdasan kinestetik/tubuh dapat dirangsang dengan gerakan seperti tarian, olah raga, terutama gerakan tubuh. Namun, tidak ditemukan aktivitas menggerakkan tubuh yang berguna untuk menyampaikan materi seperti bermain peran, permainan atau pantomim. Dan apabila hal tersebut dilakukan akan memudahkan peserta didik yang mempunyai kecenderungan kecerdasan kinestetik/tubuh untuk memahami materi yang dipelajari. Sebagaimana yang diungkapkan Armstrong bahwa aktivitas yang tepat untuk kecerdasan kinestetik/tubuh 
adalah permainan tebak gerakan tubuh, bermain peran, dan kegiatan yang melibatkan gerakan tangan (Armstrong, 2009: 82-85).

e. Kecerdasan interpersonal (interpersonal intelligence)

Kecerdasan interpersonal adalah kecerdasan yang berkaitan dengan kemampuan bekerjasama, dan berkomunikasi dengan orang lain, baik komunikasi verbal maupun non verbal. Mempunyai kepekaan terhadap perasaan, motivasi, ekspresi, dan gestur. Pada tingkatan yang lebih tinggi, dapat membaca konteks kehidupan orang lain bahkan keputusan yang akan diambil (Budiningsih, 2015: 115). Memiliki kepekaan dan rasa empati terhadap orang lain juga termasuk dalam kecerdasan ini (Helmawati, 2018: 152).

Aktivitas kecerdasan ini dilakukan dengan membentuk kelompok baik kelompok proyek membuat sesuatu, diskusi mengerjakan soal, dan kelompok permainan saat bakat minat Pramuka. Selain itu, peserta didik dibiasakan untuk antri berbaris saat mengumpulkan tugas menghormati yang lebih dulu selesai.

Guru kelas IV menyampaikan bahwa pernah juga meminta peserta didik untuk mewawancarai anggota keluarga dan kakak kelas mereka untuk mengembangkan aktivitas kecerdasan interpersonal. Pembentukan kelompok saat mengerjakan soal, dan pembuatan suatu proyek juga dilakukan saat peserta didik dirasa kesulitan jika mengerjakan sendiri dan agar bisa bekerja sama dengan teman-temannya (Fitriani, Wawancara 28/01/2020). Salahsatu peserta didik juga menyampaikan bahwa aktivitas berkelompok pernah dilakukan saat mengerjakan soal dan saat permainan tangkap bola. Berikut ini adalah dokumentasi aktivitas kecerdasan interpersonal saat mengerjakan soal dengan berkelompok.

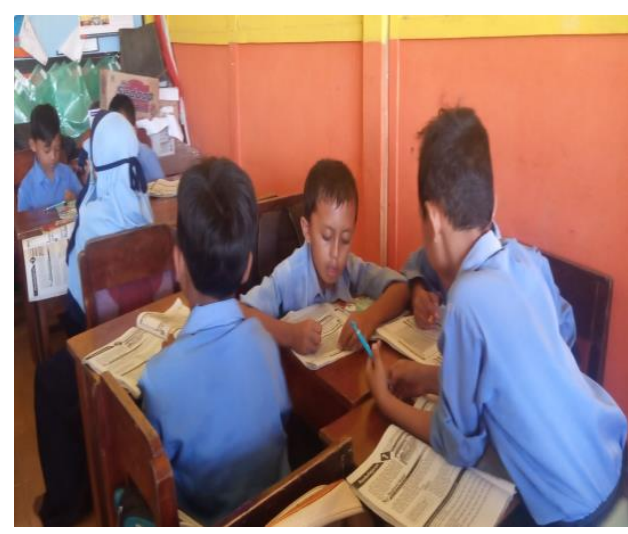

Gambar 7. Aktivitas kecerdasan interpersonal

Berdasarkan hasil temuan tersebut, aktivitas kecerdasan interpersonal sesuai dengan pendapat Helmawati (2018: 152) bahwa kecerdasan interpersonal dapat dirangsang melalui aktivitas bersama teman di sekitar. Sedangkan menurut Chatib (2018: 111-113) salah satu aktivitas yang dapat dilakukan adalah be a discover yaitu melakukan penelitian bersama untuk menghasilkan penemuan. Aktivitas tersebut selain dapat mengembangkan 
kecerdasan interpersonal juga dapat mengembangkan kecerdasan logika-matematika dan intra personal.

f. Kecerdasan intra personal (intra personal intelligence)

Kecerdasan intra personal adalah kecerdasan memahami aspek internal diri sendiri seperti refleksi diri, intuisi, dan spiritual, dapat bertanggung jawab dengan kehidupannya. Kecerdasan ini bersifat paling individual (Budiningsih, 2015: 115). Kepedulian dengan suasana hati, niat, motivasi, temperamen, keinginan, kedisiplinan diri, memahami diri sendiri, dan harga diri juga merupakan kecerdasan intrapersonal (Armstrong, 2009: 7).

Aktivitas kecerdasan intra personal yang ditemukan saat penelitian adalah guru memberikan reward kepaa peserta didik yang berani menjawab pertanyaan baik berupa pujian maupun tepuk tangan. Selain itu, ada sosialisasi cara mencuci tangan untuk menjaga kesehatan diri, mengerjakan tugas-tugas mandiri, mengingatkan peserta didik untuk percaya diri, serta mengajak memberi motivasi dengan memegang kepala masing-masing sambil mengucapkan kata-kata yang mengandung motivasi untuk siap menerima pelajaran dan tidak malas.

Selain itu, guru kelas IV menyampaikan agar peserta didik selalu sopan santun, bersikap yang baik, mengingatkan untuk menjaga kesehatan, serta mengawasi peserta didik saat makan siang di Sekolah agar mengonsumsi makanan yang sehat (Fitriani, Wawancara 28/01/2020). Salah satu peserta didik juga menyampaikan bahwa guru sering memberikan tugas mandiri, memberi nasihat setelah melakukan sholat dluha untuk selalu berdo'a dan menjaga kesehatan diri sendiri (Kafabi, Wawancara 17/01/2020). Berikut ini adalah dokumentasi aktivitas kecerdasan intra personal saat peserta didik diajak untuk memberi motivasi kepada diri sendiri.

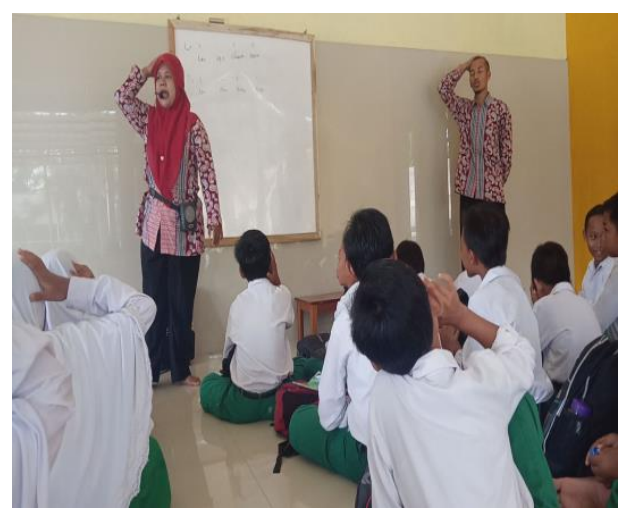

Gambar 8. Aktivitas kecerdasan intra personal

Berdasarkan hasil temuan tersebut, aktivitas kecerdasan intra personal yang dilakukan sesuai dengan pendapat Armstrong (2009: 91-92) bahwa aktivitas kecerdasan intra personal yang perlu diterapkan memberikan kesempatan peserta didik untuk 
menentukan pilihannya sendiri, dan hal tersebut dilakukan pada saat pemberian tugas mandiri. Selain itu juga melakukan one-minute reflection periods melalui aktivitas memberikan motivasi atau refleksi diri. Sedangkan menurut Helmawati (2018: 178-186), selain aktivitas tersebut guru juga dapat mengajak peserta didik untuk mengenali dirinya sendiri, memperlakukan diri sendiri dengan baik, dan membuat rencana dengan time line agar peserta didik dapat merencanakan apa yang akan dilakukan dan apa tujuan yang akan dicapai.

g. Kecerdasan musikal (musical intelligence)

Kecerdasan musikal adalah kecerdasan tentang kepekaan terhadap bunyi-bunyian, nada, irama, ritme, serta suara di sekitar (Budiningsih, 2015: 115). Beberapa aktivitas kecerdasan musikal banyak dilakukan saat kegiatan alpha zone dengan menyanyikan berbagai macam lagu anak-anak, lagu berbahasa jawa, dan lagu anjuran membaca basmalah. Selain itu, guru juga mengubah lirik lagu dengan lirik yang sesuai dengan materi keragaman agama di Indonesia beserta hari besarnya dan keragaman suku di Indonesia beserta provinsinya. Aktivitas kecerdasan musikal juga ditemukan saat kegiatan bakat minat paduan suara dan tilawatil qur'an. Tapi, kegiatan bakat minat tersebut dikhususkan untuk peserta didik yang memiliki kecenderungan kecerdasan atau bakat musikal.

Sementara itu guru kelas IV juga menyampaikan bahwa kadang guru mengubah materi menjadi sebuah lagu agar peserta didik bisa hafal dengan sendiri dengan menyanyikan lagu tersebut. dan apabila lagu itu merupakan muatan SBdP guru juga mencontohkan lagu dengan media soundsystem (Fitriani, Wawancara 28/01/2020). Peserta didik juga menyampaikan aktivitas kecerdasan musikal yang dilakukan adalah guru mencontohkan sebuah lagu, bernyanyi, dan mendengarkan musik (Muribbiyatuz Z, Wawancara 17/01/2020). Dari hasil temuan tersebut dapat diketahui bahwa teaching aids pada aktivitas kecerdasan musikal adalah teks lagu dan soundsystem. Berikut ini adalah dokumentasi aktivitas kecerdasan musikal saat menyanyikan sebuah lagu.

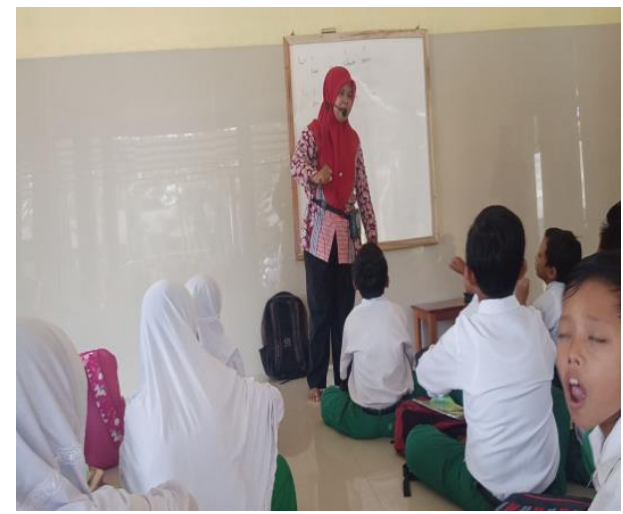

Gambar 9. Aktivitas kecerdasan musikal 
Berdasarkan data mengenai aktivitas kecerdasan musikal di atas, dapat disimpulkan bahwa aktivitas tersebut sudah tepat dilakukan karena sesuai dengan dengan pendapat Budiningsih (2015: 115), karena kecerdasan musikal adalah kepekaan terhadap bunyi-bunyian, nada, irama, ritme, serta suara di sekitar. Apa yang dilakukan tersebut juga sesuai dengan pendapat Helmawati (2018: 187-195) bahwa kecerdasan musikal bisa diekspresikan melalui kegiatan bernyanyi, mendengarkan musik, bertepuk tangan, dan memainkan alat musik.

h. Kecerdasan naturalis (naturalistic intelligence)

Kecerdasan naturalis adalah kecerdasan mengenali dan mengklasifikasikan berbagai spesies baik flora maupun fauna yang ada di lingkungannya. Termasuk kepekaan dan mengenali fenomena alam seperti bentuk awan, dan gunung. Bagi mereka yang tinggal di perkotaan memiliki kemampuan membedakan benda mati yang ada di sekitarnya (Armstrong, 2009: 7). Aktivitas kecerdasan naturalis sangat jarang dilakukan karena keterbatasan media. Aktivitas kecerdasan naturalis yang ditemukan saat penelitian adalah guru menjelaskan mengenai Sumber Daya Alam yang dapat diperbarui dan tidak dapat diperbarui. Selain itu juga melakukan aktivitas belajar di luar kelas seperti di lapangan dan jalan-jalan berkeliling di sekitar lingkungan sekolah sambil mengamati hal-hal yang ditemukan. Kelas di SD Hidayatul Murid Full Day juga dirancang dengan semi terbuka, tidak tertutup sebagaimana kelas biasanya. Dari aktivitas tersebut dapat diketahui bahwa teaching aids atau media yang digunakan adalah keadaan lingkungan sekitar sekolah.

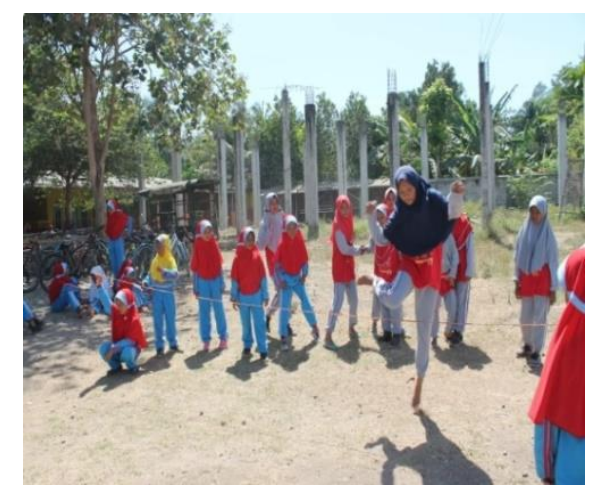

Gambar 10. Aktivitas kecerdasan naturalis

Guru kelas IV menyampaikan bahwa kecerdasan naturalis pernah dilakukan melalui eksperimen menanam kacang hijau dan kedelai baik di rumah atau di Sekolah. Di rumah juga dilakukan agar peserta didik juga bisa belajar dengan orang dewasa di rumah, pernah juga mengajak peserta didik belajar di gazebo atau di lapangan saat peserta didik bosan belajar di kelas (Fitriani, Wawancara 28/01/2020). Sedangkan menurut peserta didik belajar di luar kelas juga dilakukan saat kegiatan olah raga, jalan-jalan sambil mengamati lingkungan sekitar sekolah juga pernah diminta melakukan eksperimen seperti yang 
disampaikan oleh Guru kelas IV (Muribbiyatuz Z, Wawancara 17/01/2020). Gambar 10 di atas adalah dokumentasi aktivitas kecerdasan naturalis saat peserta didik belajar di luar kelas.

Apa yang dilakukan tersebut sesuai dengan pendapat Armstrong (2009: 94) bahwa salah satu aktivitas untuk mengembangkan kecerdasan naturalis adalah nature-walks. Adapun menurut Helmawati (2018: 197-198), ada banyak aktivitas yang bisa dilakukan untuk mengoptimalkan kecerdasan ini seperti kegiatan berkebun, melakukan interaksi dengan hewan, mengenalkan hukum sebab akibat yang berlaku di alam seperti penyebab banjir, dan memperhatikan perubahan cuaca atau gejala bencana alam. Guru juga dapat memanfaatkan media pembelajaran yang berguna untuk mengeksplorasi alam seperti mikroskop, kaca pembesar, dan teleskop.

i. Kecerdasan eksistensial (exsistensialist intelligence)

Kecerdasan eksistensial adalah kecerdasan menyadari dan menghayati keberadaan diri di dunia dan apa tujuan hidup di dunia seperti yang didapati pada seorang filsuf. Kecerdasan ini dapat berkembang melalui kontemplasi dan refleksi diri, dan kegiatan keagamaan (Budiningsih, 2015: 116).

Aktivitas kecerdasan eksistensial banyak ditemukan dalam kegiatan pembiasaan keagamaan yang dilakukan terus menerus setiap hari yaitu berdo'a sebelum dan sesudah pembelajaran, sholat berjama'ah baik sholat sunah dluha maupun sholat dluhur dan 'ashar di Sekolah, dan mengaji. Sedangkan dalam kegiatan pembelajaran di kelas pernah beberapa kali dilakukan dengan menulis puisi tentang cita-cita peserta didik serta melalui nasehat-nasehat dan pemberian motivasi atau refleksi tujuan mereka belajar.

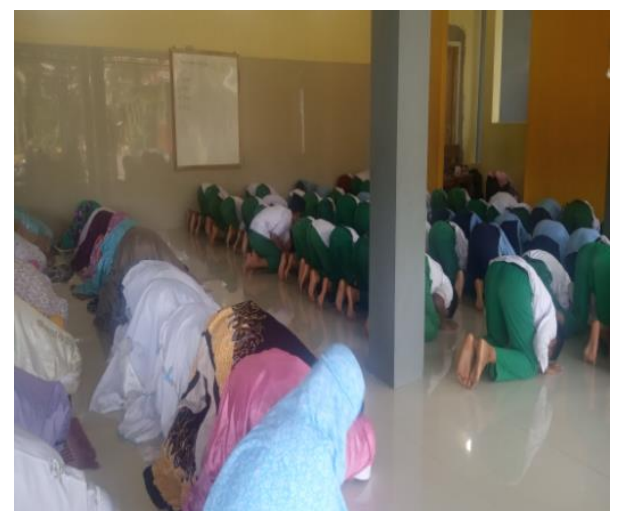

Gambar 11. Aktivitas kecerdasan eksistensial

Guru kelas IV juga menyampaikan aktivitaas kecerdasan eksistesnsial yang dilakukan dengan memberikan refleksi tujuan belajar saat peserta didik tidak fokus belajar dengan menanyakan apa tujuan mereka belajar dan apa kegunaannya untuk masa depan. Selain itu, pada hai Jum'at saat peserta didik laki-laki melaksanakan sholat Jum'at, peserta 
didik yang perempuan melakukan kegiatan keagamaan mengaji risalatul mahidl, dziba'iyah, tahlil, muhadloroh, secara bergantian setiap minggunya." (Fitriani, Wawancara 28/01/2020). Berikut ini adalah dokumentasi aktivitas kecerdasan eksistensial saat melakukan sholat dluha berjama'ah.

Aktivitas yang dilakukan untuk mengembangkan kecerdasan eksistensial tersebut sesuai dengan pendapat Budiningsih (2015: 116) yaitu kecerdasan eksistensial dapat berkembang melalui kontemplasi dan refleksi diri, serta kegiatan keagamaan. Gardner berpendapat bahwa kecerdasan eksistensial memiliki persamaan dengan kecerdasan spiritual. Oleh karena itu, kegiatan pembiasaan keagamaan yang dilakukan juga termasuk kecerdasan spiritual (Helmawati, 2018: 55).

\section{Evaluasi Pembelajaran Berbasis Multiple Intelligences}

Evaluasi pembelajaran yang dimaksud adalah penilaian pembelajaran. Penilaian pembelajaran yang diterapkan dalam pembelajaran berbasis multiple intelligences adalah penilaian autentik. Penilaian autentik menurut Peraturan menteri pendidikan dan kebudayaan tentang penilaian hasil belajar oleh pendidik pada pendidikan dasar dan pendidikan menengah menjelaskan bahwa yang dimaksud dengan penilaian autentik adalah "bentuk penilaian yang menghendaki peserta didik menampilkan sikap, menggunakan pengetahuan dan keterampilan yang diperoleh dari pembelajaran dalam melakukan tugas pada situasi sesungguhnya".

Chatib menjelaskan bahwa penilaian autentik adalah perubahan yang fundamental dari penilaian standar yaitu penilaian tradisional yang mempunyai keterbatasan untuk mengukur kemampuan secara komprehensif dan hanya menggunakan satu jenis tes. Penilaian autentik dapat mengukur tiga aspek kemampuan yaitu pengetahuan, keterampilan, dan sikap bersifat berkesinambungan, konkret, dan menggunakan berbagai bentuk penilaian tidak hanya tes (Chatib, 2018: 139-140).

Jadi, dapat disumpulkan bahwa bahwa penilaian autentik adalah penilaian yang dilakukan untuk mengukur kemampuan peserta didik menggunakan banyak bentuk penilaian dan tidak hanya menggunakan tes.

Penilaian autentik yang dilakukan dalam pembelajaran berbasis multiple intelligences di SD Hidayatul Murid Full Day diantaranya adalah tes lisan dan penilaian produk. Tes lisan dilakukan di tengah-tengah pembelajaran dengan cara guru menunjuk satu persatu peserta didik untuk menjawab pertanyaan. Guru kelas IV juga mengatakan bahwa melakukan tes lisan di sela-sela peserta didik mengerjakan sesuatu dengan menanyakan materi hari kemarin (Fitriani, Wawancara 28/01/2020). Sedangkan penilaian produk digunakan untuk menilai menilai hasil karya peserta didik berupa puisi yang mereka tulis dengan tema yang ditentukan oleh guru yaitu tentang cita-cita mereka. 
Penilaian autentik lainnya yang diterapkan adalah mengerjakan soal uraian, ulangan harian per-KD dan unjuk kerja. Mengerjakan soal uraian dilakukan pada saat peserta didik sudah mempelajari materi mengenai bangun datar persegi. Sedangkan ulangan harian per-KD dilakukan saat peerta didik selesai mempelajari satu subtema yaitu subtema 2 pada tema 6 , hebatnya cita-citaku. Adapun unjuk kerja digunakan untuk menilai pada saat peserta didik praktek mendeklamasikan puisi yang berjudul cita-citaku.

Guru kelas IV juga menambahkan penilaian autentik yang dilakukan bervariasi, tidak hanya menggunakan satu bentuk penilaian autentik saja yaitu portofolio, pengamatan, dan jurnal.

"Kita sediakan map-map di pinggir kelas itu, untuk menyimpan hasil kerja mereka, nanti terkumpul dari materi pertama sampai berakhir satu semester, jadi portofolio mereka. Nanti kalau sudah satu semester kita bagikan, ganti dengan semester yang baru. Nah kalau misalnya ada materi seperti menyanyi, tapi waktunya kurang buat praktek, kita amati saja waktu nyanyi bersama itu. Di K13 kan ada juga penilaian sikap, itu juga kita amati kesehariannya, kalau di kelas bagaimana, kalau sama temannya bagaimana, nanti itu kan jadi jurnal ada catatan sikap mereka rapor. Yang wajib disini itu penilaiannya ulangan perKD kayak minggu lalu itu, jadi tidak hanya di kelas empat saja, semua kelas itu wajib mengadakan ulangan per-KD setidaknya seminggu sekali, PTS, PAS itu juga pasti dilakukan" (Fitriani, Wawancara 28/01/2020).

Kepala Sekolah juga menyampaikan bahwa ulangan harian per-KD itu wajib dilakukan sama seperti PTS dan PAS. Sedangkan untuk penilaian harian bentuk penilaian autentik disesuaikan dengan materi (Fuadi, Wawancara 03/02/2020).

Dari data tersebut, penilaian autentik yang dilakukan sudah sesuai dengan beberapa pendapat ahli. Gardner (1983: xli) berpendapat bahwa multiple intelligences tidak hanya sebatas kemampuan untuk mengerjakan tes-tes tertentu. Kemudian, Chatib juga berpendapat bahwa penilaian autentik tidak hanya dilakukan dengan satu tes, tapi menggunakan berbagai bentuk penilaian dan memenuhi tiga ranah yaitu kognitif (pengetahuan), psikomotorik (keterampilan), dan afektif (sikap). Pada penelitian ini, penilaian kognitif berupa tes lisan, tugas mandiri berupa soal uraian, ulangan harian per-KD, dan penilaian tengah maupun akhir semester, penelitian psikomotorik berupa unjuk kerja praktek mendeklamasikan puisi, penilaian produk dan portofolio, sedangkan penilaian afektif berupa pengamatan dan jurnal sikap peserta didik.

Bentuk-bentuk penilaian autentik yang dilakukan juga sudah sesuai dengan dengan Permendikbud RI, No. 104 tahun 2014 tentang penilaian hasil belajar oleh pendidik pada pendidikan dasar dan pendidikan menengah. Dalam aturan Permendikbud tersebut disebutkan bahwa bentuk penilaian autentik mencakup penilaian berdasarkan pengamatan, tugas ke lapangan, portofolio, proyek, produk, jurnal, unjuk kerja, serta penilaian diri. 


\section{KESIMPULAN DAN SARAN}

Berdasarkan pemaparan di atas, implementasi pembelajaran berbasis multiple intelligences di SD Hidayatul Murid Full Day ada tiga tahap yaitu, perencanaan, pelaksanaan, dan evaluasi. Pada tahap perencanaan yang dilaksanakan adalah mengetahui kecerdasan atau bakat peserta didik melalui wawancara dan tes kemampuan, serta menyusun Rencana Pelaksanaan Pembelajaran (RPP). Pada tahap pelaksanaan, pembelajaran berbasis multiple intelligences diawali dengan kegiatan alpha zone seperti senam otak dan menyanyi, dilanjutkan dengan scene setting/warmer berupa kegiatan yang membawa peserta didik membangun konsep materi atau mengulang materi sebelumnya, kemudian aktivitas kesembilan macam kecerdasan. Pada tahap evaluasi, penilaian yang wajib dilaksanakan adalah penilaian ulangan harian per-KD, penilaian tengah semester, dan penilaian akhir semester. Sedangkan selain itu, melaksanakan penilaian autentik yang bentuknya disesuaikan dengan materi.

\section{DAFTAR PUSTAKA}

Armstrong, Thomas. (2009). Multiple Intelligences in the Classroom. USA: ASCD.

Baiquni, Ahmad. (2014). Tafsir Salman: Tafsir Ilmiah Juz 'Amma. Bandung: YPM Salman ITB.

Budiningsih, Asri. Belajar dan Pembelajaran. Jakarta: PT Rineka Cipta, 2015.

Chatib, Munif. (2018). Sekolahnya Manusia. Bandung: Penerbit Kaifa.

Departemen Agama RI. (2013). Al-Qur'an dan Terjemahnya. Bandung: CV Penerbit Diponegoro.

Gardner, Howard. (1983). Frames Of Mind: The Theory of Multiple Intelligences. NewYork: Basicbooks.

Helmawati. (2018). Mendidik Anak Berprestasi Melalui 10 Kecerdasan. Bandung: PT Remaja Rosdakarya.

Kemendikbud RI, Permendikbud RI, No. 104 tahun 2014 tentang penilaian hasil belajar oleh pendidik pada pendidikan dasar dan pendidikan menengah.

Lanvin, Bruno dan Felipe Monteiro. (2019). The Global Talent Competitiviness Index 2019. Prancis: INSEAD.

Pradini Dzilhijjah, Sarah. (2016). Implementasi Pembelajaran Berbasis Multiple Intelligences pada siswa Kelas III di SD Jogja Green School. Yogyakarta: Universitas Negeri Yogyakarta.

Sekretariat Negara RI, UU No. 20 tahun 2003 tentang Sistem Pendidikan Nasional.

Tim penyusun. (2018). Potret Pendidikan Indonesia: Statisktik Pendidikan Indonesia 201. Jakarta: Badan Pusat Statistik. 